\title{
An Analysis of Economics in International Law Using the Feminist Theory
}

\author{
Özlem İngün Karkış ${ }^{1}$ \\ ${ }^{1}$ Dr. Özlem İngün Karkış, Istanbul, Turkey. \\ Correspondence: Dr. Özlem İngün Karkış, Istanbul, Turkey.
}

Received: April 5, 2016

Accepted: April 20, 2016

Available online: April 22, 2016

doi:10.11114/ijsss.v4i5.1521

URL: http://dx.doi.org/10.11114/ijsss.v4i5.1521

\begin{abstract}
This paper aims to analyze why and how gender issues matter in international economic law by applying Feminist theory. For this purpose, the paper begins with a short account of Feminist theory of international law. However, even though Feminist theorists are trying to elaborate the most effective methodology that can serve better in protecting women's rights, there is no single Feminist approach to the international law and economics. Therefore, this paper goes further by examining Feminist Method(s) in international law. Lastly, international economic discourse in international law will critically be examined through the application of feminist theories to international economics.
\end{abstract}

Keywords: International Law, International Economy, Women' Movement, Feminist Theory

\section{Introduction}

Feminist Law came into existence belonging to 1960's feminists' protesting the discourse of "male dominance" and it has become the natural and supplemental factors of this movement. Regardless of race, class, age and ability, women have demanded for feminist justice as equal partners of "the social contract" that has been assisted by law and legal systems. In this context "Feminist Law" is the way of constituting a feminist theory and also analysing the relations between law and women with regards to all women. (Weisberg, 1993: 22).

The Feminist Law is a philosophy of law that defends the equality of economical, political and social of sexes (Arat, 2006: 54). The Theories of Feminist Law reach a consensus on the belief of the society, which is shaped and managed by men and also patriarchy to the contrary on differences between schools of thought. The Feminist Law analyses and criticizes the situation of women in a patriarchal social structure. It researches the nature and measures of overpowered women. It also finds out the law's role in maintenance and guarding the patriarchy in law. All that it tries to determine the methods of get rid of patriarchy (Arat, 2006: 56).

As it is commonly acknowledged, human rights are for all human beings. In practice, however, it is not quite so. International laws in general and international human rights in particular are constructed upon particularly male assumptions and experiences of life where man is taken to represent the human.

The reason for taking part of women issue in international law can be explained in the context of public space and private space. The differences dependent to women are being ignored on the subject of establishing law grounding with human rights (Charlesworth, 1994: 60). The United Nations of Economic, Social and Cultural Bill of Rights reproduce the gendered structure of public and private spaces. This contract article 7 is arranged basically according to working continuous on public space (Charlesworth, 1994: 74). Merely in large part of women in the world are working free of charge indoors, or in other words, in private space. Therefore, women get limited benefits from subjected united human rights guarding.

The countries contracting international treaties take the human rights under protection. The country, which has contracted one of the conventions, guarantees to contract administration and not to renege on the contract articles. The country gives that guarantee against both its citizens and the other countries, which have approved and signed the same contracts.

The Universal Declaration of Human Rights rejects all kinds of discrimination including the gender gap and declares that all human beings are born equal and free with respect to rights and honors. The admitted decisions and also advisory decisions that are concerted by United Nations aim to provide the equality between men and women. Unfortunately the gender apartheid is proceeding widely despite these several documents. 
The gender apartheid infringes on the contract article. It also obstructs women from joining the economic, social, political and cultural life easily and it deprives women of economical activities. Thus, women cannot increase their ability and become more impoverished. Consequently, women cannot find enough chances to have training and business opportunities.

\section{Feminist Approaches to International Law}

The so-called 'women problem' is doubtlessly a complicated phenomenon containing such as economic, political, psychological, sociological, and cultural dimensions. If international law can be seen as a mechanism for distributing power resources in the international and national communities, then international economic law is the domain in which this unequal power distribution takes place in its most constrained form(s). Because (international) economy in this respect is not only a traditionally male dominated sphere of (international) public life, but also a domain that reveals the unequal power distribution between different genders more clearly.

Feminism can largely be defined as the philosophy and/or political movements that aim to wipe away all forms of sexism. Feminism exposes the gender mainstreaming in basic category. This conceptualization verifies that the hierarchy creates a fundamental sovereignty and power, which shape the society. Furthermore, it displays that men are dominant and women dependent on men. Feminism argues that this situation is not natural, it can be changed and it should be changed.

According to the Feminist theorists the methods for reaching the knowledge and objectivity reflect the male views. The prevalent inadequacy of research methods first became apparent when women tried to re-construct the(ir) history. They realized that women have not appeared in the history, it has been built just on males due to the fact that men have written history for themselves.

The women problem is a complicated phenomenon which contain lots of components like; economics, politics, psychology and sociology. In general, we can describe feminism as a libertarian view that challenges gender discriminations in any case; defines the politics, economics and social equality between genders. This description brings about the disequilibrium, oppression and exploitation in every situation and the efforts for rescuing women from the subsidiary positions. The problem is not the misandry; it's just the sexism.

Feminism exposes gender mainstreaming in basic category. This conceptualization verifies that the hierarchy creates a fundamental sovereignty and power, which shapes the society. Furthermore, it displays that men are dominant and women dependent on men. Feminism argues that this situation is not natural, it can be changed also it should be changed.

Gender mainstreaming explains the characteristics of being women and men in socialization processes and culture. It shows that femininity and manhood are not natural roles; they are defined and learned culturally (Çakır, 2007: 415). Throughout history in all communities women have been subaltern. In the 17th and 18th centuries, rebellion was exposed against these circumstances. In this period, capitalism emerged and the production process was changed from public space to family. After the segregation of house and work, bourgeoisie men joined the production while women were alienated from production process and identified with home (Çakır, 2007: 416).

Feminism differentiates in the way of perceiving the patriarchal system and constructing politics to challenge it. In the 19th and 20th centuries various types of women leagued together from different geosciences. They built institutions and expressed that they want equal rights with men. This period is named; "First Wave of Feminism" and it was experienced distinctly in different countries (Çakır, 2007: 418).

Liberal feminist theorists come from natural rights custom and they say women have same basis rights with men as citizens and being human. Their elementary ideas are (Donovan, 2001: 22-23):

1- Believing the mind

2- Belief in women and men have same spirits and rational abilities

3- Belief in education for social change and development and also social transformation

4- Standpoint on individual loneliness depends on human's liberty and honor

In conclusion, Liberal feminist theorists adhere to the natural right doctrine. They insist on voting rights (Donovan, 2001: 27-28). They adopt that public space is named as men's world and women are house bounded. They believe these problems can be solved by abolishing that discrimination. Liberal feminist theorists gave a lot of importance to the matter of women being full components of human society.

In recent years, liberal feminism's views about neglecting the distinction between men and women were argued. And it is understood that the problem cannot be solved only by legislating for equal opportunities all the same it is realized these regulations were insensitive to gender-mainstreaming. Later on it's being accepted that the necessity is about 
making laws that considers gender-mainstreaming discrimination and also institutional regulations (Çakır, 2007: 446).

Cultural feminist theorists look for a broad cultural transformation. They accept the importance of critical thinking and self-development. But mainly they insist on life's irrationality, heuristicality and collectivity. They do not emphasize the similarities between women and men; they generally indicate women's qualifications as self-power, honor and differences like source of public renewals. They think alternatives for marriage and religion (Donovan, 2001: 69-70). According to Cultural feminist theorists the subjects about family relationship are regulated in men's perspectives. They offer radical changes in home life. The patriarchal aspects should be eliminated.

Cultural feminist theory is based on the matriarchal point of view. They put forward feminine characteristics like cooperation, pacifism and intuitivism. And finally they accept all human beings can be educated (Donovan, 2001: 126).

Marx and Engels's ideas are very important in developing process of Feminist Theory. Especially in women's consciousness raising Marxist historical materialistic thought is very efficient. Socialist feminist theorists accept the similarities between women and the proletariat (Donovan, 2001: 133). They give a place to gender mainstreaming beside the proletariat. They tried to expose who derives personal benefit from women's labour and the basics of women's material oppression (Donovan, 2001: 133).

These theorists offer a new alternative family style against patriarchal social system's family. They defend socialization of home labours and waging home works. Marxist theory cares about labour and social feminist theory cares about sexism and also Marxist method depends on dialectic materialism. However social feminist method depends on feminist consciousness continuing to rise (Donovan, 2001: 167).

Social feminist theorists criticize Marxism in the matter of ignoring sexual relations. They say that Marxism was developed in the circumstances of men and it accepts the relations between genders as usual. According to this, women were abandoned from the Marxist problematic. Marxism's personhood category does not include women. It connects the problem to capitalism and in this context women's oppression is because of political, economic and social structures (Çakır, 2007: 459).

Radical feminist theorists say the result of discrimination is about the biological difference between men and women. And they think it's about paradox of family institution. According to them women and men are connected to each other with power relations. In this context they suggest women should set a mobilization against men's benefits for their common benefits.

Radical feminist thesis are; personal is political, patriarchy takes place in the root of under pressure the women not the capitalism, women should challenge together the men who oppress them, men and women are fundamentally different, they have different cultures, womenmades and thoughts (Donovan, 2001: 268-69). The sexism that exists on the foundation of men and women relations creates the power relation depending on male dominance. Radical feminist theorists think women bodies and identities can be liberalized with reconceptualising the sexism as female-centred. And they also insist that the reasons behind the oppression of women arise from female biology and fertility (Çakır, 2007: 449).

By handling international law generally, it points out that all human beings have the right to be treated as humans. These rights are sourced of being human they are inalienable and nonassignable rights. Also these rights can be asserted against to state, private persons and organizations (Berktay, 2004).

In an ideal world there should not be essentialness to argue about women rights and child rights. The human rights should include all the humanity's rights. But we do not live in a world formalized like that. Moreover, human rights doctrine and its liberty, equality concepts that build its norms and principles are defined in certain terms by social circumstances. So human rights and the concept of "human" include the historical and concrete contents that include class, race and gender blindness (Berktay, 2004).

The concept of equality should be accepted as including all individuals as universal principle. Purely it is understood that it does not include the women. The women are excluded from equality perspective that is based on natural law human rights. By understanding deprived of this equality, they had awareness of belonging to the oppressed group. Thus, they made a consensus on the subject of challenging and changing the women's situation into one surrounded by human rights (Çakır, 1996: 417).

The international human law ignores social and economic differences beside human's individual distinctions, their different abilities and human wanting. It assumes that all humans are non-classed, non-raced and non-gendered. But all human beings live in the society belonging to specific race, ethnic group and also gender. And in this declared society there are no equal relations, but it includes hierarchal relations, which dominate with power. Behind the human abstraction of human rights discourse, there is a concrete human who represents the hegemonic in power relations. This human is identified as white, bourgeois and also male (Berktay, 2004). 
Since the early 1990s, the analyses of gender and gender justice have become increasingly complex. When talking about gender it means women in general or their absence from international law and politics.

When the process of investigation the sex of international law, it widely can be seen the image of male body upon that the state is built and it depends upon and reinforces ideas about masculinity and femininity (Charlesworth, 1999: 207).

The place of international law itself is very different today from the past. Today the discipline is facing considerable threats and they emerge from the external forces of globalization and extremism beside internal unwillingness of major players to observe its restraints and to act within its institutions. But still there are not enough changes in this area; for example about the participation of women in international policy and decision-making bodies (Chinkin, 2003: 56).

The feminist international law project adds a new institution, ensures the inclusion of women in the composition of decision or policy-making committees or extends the jurisdiction of an institution by including crimes against women in the international criminal law tribunals. In this context the necessities are to expose and challenge with the gender biases of international law and its privileged hierarchies (Chinkin, 2003: 56).

After all these we can say that international human rights consist of the patriarchy and male hegemony and it acts in gendered ways. And it has conceptualized according to natural rights theory. As McDonagh emphasizes; one of the major purposes of the liberal state is to protect property as generated by productive labourers presumed to be equal. All individuals are equal and free in the sense of natural law. According to John Locke the origin of the state is a contract that has been made to dispose of the nature situation where all individuals are equal (McDonagh, 2002: 548). But the individual in liberal theory is not a universal and gender-beyond notion even though it is claimed the opposite. The new rights and freedoms have thought for bourgeois men. The Liberal Nature Rights is not coincidence with regard to individual rights and freedom. This contrast brings the distinctiveness of public and private spaces come to light (Berktay, 2003: 39). Another liberal theorist Rousseau mentions an individual who has rigged with all natural rights. But it is an abstract concept the sexuality is unclear. He cares about individual's freedom more than everyone but according to him women should not be free. John Stuart Mill, another liberal theorist, emphasises to equalize women in all areas. Also he told that being lowliness in the society roots in culture (Çakır, 2007: 440-444).

Like the problems that feminist theory encounters while trying to build a feminist method, the international law faces the same; masculinity, discrimination, outlawing from specific areas, being appendages of men and being pushed into subsidiary.

\section{Feminist Methods in International Law}

Women researches are emerged for realizing the aim of building epistemology for women to produce knowledge for themselves. It has posed questions to sciences' definitions, methods, settled norms and approaches (Çakır, 1996: 305).

The first development is accrued in positivist science with criticizing it. Positivism does not problematize the relation between subject and object. It says that when the real world is being examined, knowledge should not include the subject. But feminist theorists argue against that and they defend the subject is too important for acquiring information and which subject with which reason asks which questions and finally effect the last knowledge.

In the process of feminist knowledge generation, these feminist theorists mentioned below compromise on there is a contradiction between the theories and methods in social sciences and feminism's political aims. The theorists address the problem of forming a feminist research and theorize (Çakır, 1996: 310). One of the important theorists Stanley and Wise argue that all women do not share same experiences so there are various questions and answers according to different culture: (Stanley and Wise, 2013: 21-22).

“... Women share 'experiences od oppression' is not to say that we share the same experiences. The social context within which different kinds of women live, work, struggle and make sense of their lives differ widely across the world and between different groupings of women. We argue that the experience of 'women' is ontologically fractured and complex because we do not all share one single and unseamed material reality. We also suggested that the category 'women' used in academic feminist writing then (and, to an extend, now) actually reflected the experiences and analyses of white, middle-class, heterosexual, Frist World women only, yet treated these as universals".

Feminist research process is a dynamic process and reflects the experiences of women. Women who have different experiences produce theory through their experiences. It is the fact that each country, class and culture has different status of women. In this circumstance it can be said that there is not a monolithic category of women also besides feminism. But it can be said that science has a gendered structure, which should be transformed by women.

With arguing the contents of science and also science's structure provided that science has a gendered structure. It is just the product of male ideology. That's why women acted to remove science from being only men's area that only explains men's experiences. So women researches emerged due to these enterprises (Çakır, 1996: 306-307). 
The methods for reaching the knowledge and objectivity reflect the male views. The prevalent research methods' inadequacy occurred firstly when women tried to construct their history. They realized that no women appeared in the history, it has been built just on males. It is because of history was written by men for themselves.

The basis assumption is that; there is a paradox between the theories and methodologies in social sciences and the feminism's political aims. If women use these methodologies, it also transforms itself into pressure form. Hence women research should criticize these quantitative research methods and sciences (Çakır, 1996: 308-310)

The feminist research differentiates between the quantitative male methods and qualitative female methods. It gives more attention to qualitative methods by reason of bringing into the open women's experiences because quantitative research process goes as hierarchic and the collected data reflect the expected movements not the reality (Çakır, 1996: 312).

Feminist theorists say the hierarchic relation between researcher and investigated damage the researches being scientific. Therefore they use the method of verbal history, the techniques of consciousness raising, field researches and experiences of women beside settled scientific researches (Çakır, 1996: 315). And they think women's experiences should be added in the process of investigation. This is because experiences are very important within the process of research. For understanding women's oppression, oppression results should be examined and added in the researches.

Beside all these views, there is still the absence of a settled feminist method. And some researchers complain about it. However some of them think it's useful for the theory. Because it provides the investigation if there has been a settled method, there would not be so much researches. And in doing justice to idea that the most important obstacle that women researchers face is the male-dominant view in all disciplines and theoretical studies.

Also some theorists argue that men's attending in women researches by women. They challenge to this argument and try to make that area only women's and use men as a side of putting pressure on females.

For feminist research some methodological principles should exist and they are; conscious partials should be adopted, vertical relation should abandon it's place to horizontal relation, women researches should be in close relation with women's movement and acts, academics should give up arrogance, to abstract thinking and illiberalness, investigation the reality of included pressure should be carried out by battered women not the specialists, women should analyze both individual and social histories, and finally women should collectivize their experiences to adopt their history (Çakır, 1996: 32-56). The necessity throughout the feminist research is adopting concrete feminist research processes, not adapting to existed polarized models (Çakır, 1996: 69).

Feminist epistemology means to assert that a feminist research has arisen from women's material realisms. By this way it can be exerted that it includes existing a connectional language that is used in epistemological arguments, it is settled and being used in broad discipline groups and being named feminist look epistemology and also important treaties that bring syntheses of feminist philosophy (Çakır, 1996: 71).

There is a conflict between the theories and methodologies in social sciences and political aims of women's movement. The positivist and quantitative survey methods should be criticized if women's studies will be used as a means to women's freedom. Also women's studies turn into a tool of restraint if they use these old methods (Mies, 1983: 68).

\section{Seeing International Economic Discourse From The Window of The Feminist Economic Theory}

Feminist researchers emphasize that international law presents a world that is surrounded with benefits and priorities of men and especially including their economic and social needs (Charlesworth, Chinkin and Wright, 1991: 615). The reason of occurring international law of women has been explained in the context of public and private spaces. The differences about women are neglected in the international law (Charlesworth, 94: 60). In 80s the researches have increased regarding to women' situation and developing a point of view in international law.

Feminist researches focus on the disparities in economic position and unequal impact of rules of international law on women (Charlesworth, Chinkin and Wright, 1991: 618). The feminist theorists have researched the discrimination of public and private spaces of settled law, the effects of limiting women with private space in domestic legal order, substantial part of human rights accepted at an international level are nonsense in respect to the status of women and the effects on women of law on protection of the family (Alpkaya, 1992: 11-12).

Feminist law theorists' researching can provide to generalize women's economic independence and make improvement in economic structure. It can also help all women including rural regions to reach production resources, opportunities and social services equally by implementation of the contract. In this way increasing poverty can be brought under control.

A feminist analysis of economics requires substantial, conceptual, analytical and epistemological shifts. By this means it provides a new frame to understand global economy, women's position in that system and the law internationally settled including sexes (Nagar, Lawson, etc., 2002: 279). 
The category of economic, social and cultural rights in international law includes right to work, having fair and proper working conditions, union rights, right to education and so on. These rights have got changed according to international documents. The fact remains that the universal and regional contracts related to human rights prohibition the gender apartheid and consist some article of agreement accenting the equality of men and women (Alpkaya, 1992: 25).

As the other areas in international law; the work place, economics and politics where power and authority are exercised, regard according to men's interests. Nevertheless, the world of home life, children and private life are accepted as women's spheres (Nagar, Lawson, etc., 2002: 626). International economic discourse tends to identify sexes in the way of gender bias in favour of men. The women's rights surround all rights areas such as economic, social, cultural. And for this reason women's right cannot be handled by itself and isolated. These rights can be practiced as late as making the social, economic and political conditions eligible that surround them (Berktay, 2003: 62). Also it can be distinguished by examining the international law in the frame of economics.

As globalization has changed the ways that people apprehend the political and economic space, a feminist discourse of globalization end economic has emerged. In this context the best resistance strategies are based on the new realities of global economic identity for women (Bergeron, 2001: 995).

When women enter in international law they are viewed in the ways of victims, mothers and in need of protections. International lawyers should recognize the role of economic exploitation in the position of women (Charlesworth, 1999: 384).

Women are invisible in international economic discourse because economic visibility depends on working in the public space. But women are settled in private space in general; it's categorized as unproductive, unoccupied and economically inactive (Charlesworth, 1999: 640).

International law focuses on labour power and security of them. It does not discuss from the viewpoint of women and their anxieties in working life; sexual abuse, reduced income, working conditions, difficulties on promotions.

For example the operation of the public and private distinction in international economic measurement excludes women from many aid programs due to perceiving them as less productive than men and not being considered to be workers. Although increasing industrialization in recent years has brought excessive employment opportunities for women, this improvement has not increased their economic independence, social standing and also had little impact on women's equalities. Women are employing in the lowest paid and lowest status jobs without career paths. Besides that their working conditions are often discriminatory and insecure (Charlesworth, 1999: 641).

Women have often found themselves in a problematic position class. Women's works are performed under patriarchy, a system of rules and gender domination (Gibson and Graham, 2006: 64). The human capital theories see the main problem as wage discrimination in which equally qualified persons are given differing rewards for the same type of work. The dual labour market theories also see the main problem as job discrimination in which equally qualified workers are given unequal jobs (Pinch and Storey, 1992: 198). In contrast to these theories the feminist theory sees the main problem in gender discrimination and settled in the frame of androcentric political and economical structures.

The studies that have identified gender differences are thought of in the context of male hegemony. As it's seen the world has been fashioned by men and not surprisingly they have organized it to make things easy on themselves (Gunkel, Lusk, etc., 2007: 58). Gender stereotypes are a set of beliefs and agreements that prescribe differences between men and women in their attitudes, values, interest, social relations and occupations.

According to these categorization men are perceived to be strong, active, competitive and tough, focusing on dominance, autonomy and economic achievements. Beside that women are suited for tender roles as caring home, children and people; they are concerned with nurturance, affiliation and the quality of family life (Gunkel, Lusk, etc., 2007: 59-60).

The gender discrimination is reasonable in characterizing employees' preferences for job attributes and also provides useful information to design compensation plans. And it is assumed that men would value earnings, challenge, advancement, freedom, training and using skills more highly than women. All these source from the factor of satisfying the masculine stereotypical needs of economic success. In compression women value positive interpersonal relationships, security, fringe benefits and family related factors more than men because they fulfil the stereotypically feminine needs of family, social affiliation and quality of family life (Gunkel, Lusk, etc., 2007: 60).

In general women are seen as a reserve army of labour or buffer workforce. The women are being used a substitute for male workers, they are being employed in part-time works and also using female labour is accepted as a true flexibility and cost-cutting strategy (Pinch and Storey: 198).

It's necessary to refer to the World Economic Forums to analyze and understand the discrimination in economic structures of internationally. The World Economic Forum convenes global leaders from business, policy-making and also civil society to find creative and sustainable solutions to the challenges facing the today's world. One of the 
important societal and economic challenges is the persistent gap between women and men in their access to resources and opportunities (Schwab, 2006).

In 2001 the World Economic Forum built its Women Leaders Programme to support the advancement of women to positions of leadership and to promote consideration of the issues affecting women's life. Since 2002 the Forum's Global Competitiveness Reports have provided data on the qualitative aspects of women's participation in workforce. The Forum has begun to incorporate aspects of gender equality in its measures of competitiveness and showing that the advancement of women is an important strategic issue with a potential impact on the growth of nations in the latest researches. And The Global Gender Gap Report 2006, the second in the series contains unique new methodologies to show the size of the gap between women and men in four critical areas; economic participation and opportunity, educational attainment, health and survival and political empowerment (Schwab, 2006).

In May 2005, one of the World Economic Forum's studies was attempting to assess the size of the gender gap in 58 countries using economic criteria. The index that prepared in The Report 2006 covers over 115 economies, including all current and candidate European Union countries, 20 from Latin America and the Caribbean, over 20 from sub-Saharan Africa and 10 from the Arab world. This study assesses the level of equality between women and men by merging publicly available data from the World Economic Forum's Executive Opinion Survey. And poorly it's found that no country in the world has yet managed to eliminate the gender gap (Greig and Hausmann, etc., 2006: 3).

Gender-based inequality is a phenomenon that transcends the majority of the world's cultures, religions, nations and income groups. In most countries the differences and inequalities between women and men are manifest in the responsibilities each are assigned and in their access to control over resources and in decision making opportunities (Greig and Hausmann, etc., 2006: 3).

The Gender Gap Index, which had been prepared in 2006, seeks to reflect gender outcomes and makes no prescriptions as to whether or how governments or other organizations should strive to change these outcomes. Thus it does not include variables that measure policies or means to eliminate the gender gap (Greig and Hausmann, etc., 2006: 21).

As we mentioned international law has no distinction between the economic position of men and women. It uses neutral and same language of economics and development for women too. And it does not challenge the hegemony of men over women in economics and does not mention that women's work life is different than men's (Greig and Hausmann, etc., 2006: 641). In the last periods UN deliberations have paid more attention to the situation of women in economics. But it's not sufficient to recover their position beyond men's.

For stopping these discriminations and unfairness, women rights should be accepted as human rights and international law should include women themselves not within male. The governments must avert the attacks against as political, economic and cultural to women's rights, and their desires. And also states, all institutions and non-governmental organizations should cooperate for these essential aims.

\section{Conclusion}

As it is seen in the frame of discussions there is not any settled method in Feminist Theory yet. There are various ideas on that point but theorists have not reached a consensus on it. Most theorists have an agreement on the form of knowledge. They agree on that science should include the experiences of researchers. But it can be harmful for the knowledge's reality because science should include concrete knowledge. And if the research process includes researcher's emotions and experiences it can be changed in every culture and society. Cause the culture and the structure of society affect the experiences and act. Thus it becomes impossible to develop a method that prevails in all societies. If experiences are added to the process of research, it can damage the reality.

Some theorists discuss men's contributions to the theory. According to me it's the different type of discrimination. And we cannot understand the discrimination and also differentness with eliminating the men. Also feminists express being a side of, but when we talk about the science being side of is not scientific. So they contrast with themselves and their desires.

We should keep in mind that feminist view affects the process of research and its consequences. Feminist science if and only is done its duty by transforming into feminist act with scientific methods and also becoming conscious about the real world.

As it is mentioned feminism has different types of movements and each of them handle the problem of gender discriminations in different ways and methods. These varieties of the feminist movement provide power and also expand it to broader areas. Women can use different methods and approaches to settle women rights all over each society and culture.

By trying to settle women rights in the world order, laws that protect the women's rights are accurately essential. Analyzing the discrimination between women and men is necessary to understand women's negligence and underestimating from international law and also economic structures. We live in the world that is settled in the frame of 
patriarchal benefits and mentality. Women are under pressure by men and the system that is made by them.

The economic structures intersect with sexism and provide producing distinct. It is now explicit that gender analysis is crucial in understanding issues ranging from the operation of the global economy to liberalism. Women rights should be handled as human rights it should not be differentiated from the men's rights. If it continues as it's now, it has been the crime against humanity.

\section{References}

Alpkaya, G. (1992). Uluslararası Hukukta Kadın - Uluslararası Hukukta Kadının Durumuna İlişkin Bazı Veriler,Ankara: Ankara Üniversitesi Siyasal Bilgiler Fakültesi Dergisi, 99, 11-44.

Arat, N. (2006). Feminist Hukuk, Kadın Araştırmaları Dergisi, 9, 53-65.

Bergeron, S. (2001). Political Economy Discourses of Globalization and Feminist Politics, Journal of Women in Culture and Society, 26(4), 995.

Berktay, F. (2004). Kadınların İnsan Haklarının Gelişimi ve Türkiye, Sivil Toplum ve Demokrasi Konferans Yazıları, 7. http://stk.bilgi.edu.tr/media/uploads/2015/02/01/berktay_std_7.pdf.

Berktay, F. (2003). Tarihin Cinsiyeti, İstanbul: Metis Yayınları, 35-65.

Çakır, S. (2007). Feminizm: Ataerkil İktidarın Eleştirisi, in 19. Yüzyıldan 20. Yüzyıla Modern Siyasal İdeolojiler, Birsen Örs (Ed.), İstanbul: Bilgi Üniversitesi Yay., 415.

Çakır, S. (1996). Kadın Araştırmaları Bilimde Neleri, Nasıl Sorguluyor, Neleri Değiştirmek İstiyor?, 4. Ulusal Sosyal Bilimler Kongresi Bildiriler, in İnsan-Toplum-Bilim, Kuvvet Lordoğlu (Ed.), Kavram Yayıncılık,

Charlesworth, H. (1999).The Gender of International Law, American Society of International Law. Proceedings of the Annual Meeting, 207.

Charlesworth, H. (1994). What are "Women's International Human Rights?", in Human Rights of Women: National and International Perspectives, Rebecca J. Cook (Ed.), ABD: University of Pennsylvania Press, 60.

Charlesworth, H., Chinkin, C., \& Wright, S. (Oct., 1991). Feminist Approaches to International Law, The American Journal of International Law, 85(4), 613-645.

Chinkin, C. (2003). Reconceiving Reality: A Ten-Year Peerspective, American Society of International Law, Proceeding of the Annual Meeting, 56.

Donovan, J. (2001). Feminist Teori, Aksu Bora, Meltem Ağduk, Fevziye Sayılan (çev.), İstanbul: İletişim Yayınları.

Gibson, J. K., \& Graham, K. (2006). The End of Capitalism (As We Knew It), University of Minnesota Press.

Greig, F., Hausmann, R., Tyson, L. D., \& Zahidi, S. (2006). The Gender Gap Index 2006: A New Framework for Measuring Equality, World Economic Forum, 3.

Gunkel, M., Lusk, E. J., Wolff, B., \& Li, F. (January 2007). Gender-specific Effects at Work: An Empirical Study of Four Countries, Gender, Work and Organization, 14(1), 58.

McDonagh, E. (3/2002). Political Citizenship and Democratization: The Gender Paradox, The American Political Science Review, 96, 535-552

Mies, M. (1993). Towards a Methodology for Feminist Research, in Theories of Women's Studies, 64-80, Gloria Bowles and Renata Duelli Klein (Eds.), Reutledge-Kean Paul, London-New York.

Nagar, R., Lawson, V., McDowell, L., \& Hanson, S. ( 2002). Locating Globalization: Feminist (Re)readings of the Subjects and Spaces of Globalization, Economic Geography, 78(3), 279.

https://geography.washington.edu/publications/feminist-readings-subjects-and-spaces-globalization.

Pinch, S., \& Storey, A. (1992). Flexibility, Gender and Part-time Work: Evidence From a Survey of the Economically Active, Transactions of the Institute of British Geographers, New Series, 17(2), 198.

Schwab, K. (2006). Preface of the Global Gender Gap Report 2006, World Economic Forum, Geneva, Switzerland.

Stanley, L., \& Sue, W. (2013). Method, Methodology and Epistemology in Feminist Research Process, in Feminist Praxis, Liz Stanley (Ed.), 20-62, Routledge, London\&New York, (first edition is in 1990).

Weisberg, D. K. (Ed.) (1993). Feminist Legal Theory, Philadelphia: Temple University.

\section{(cc) EY}

This work is licensed under a Creative Commons Attribution 3.0 License. 